\title{
SENSING AND SIGNALING FOR PEROXISOME AUTOPHAGIC DEGRADATION (PEXOPHAGY) IN YEASTS
}

\author{
A. A. $\operatorname{SIBIRNY1,2}$ \\ ${ }^{1}$ Institute of Cell Biology, National Academy of Sciences of Ukraine, Lviv; \\ ${ }^{2}$ University of Rzeszow, Poland
}

\begin{abstract}
Yeast cells, similarly to cells of other eukaryotic organisms, possess intracellular organelles, including that of peroxisomes also known as microbodies. Enzymes of oxidative metabolism, mainly hydrogen peroxide generating oxidases, catalase, some enzymes of glyoxylic cycle and enzymes involved in catabolism of unusual carbon sources (n-alkanes, methanol) are located in peroxisomes. Especially important role is played by peroxisomes in methylotrophic yeasts, unique eukaryotic organisms capable to utilize one-carbon compound, methanol. Active proliferation and biogenesis of peroxisomes occur on methanol, so these organelles can occupy between 30 and $80 \%$ of cellular volume. After shift of methanol-grown cells into media with multicarbon substrates, such as glucose or ethanol, an excess of peroxisomes degrades in the specific process known as autophagic degradation of peroxisomes or pexophagy. There are 36 AuTophaGy related genes, known as ATG genes, which products are also involved in pexophagy. At the same time, not much is known on mechanisms of glucose and ethanol sensing and signaling which initiate pexophagy process. Proteins Pfk1( $\alpha$-subunit of phosphofructokinase), Slt 2 (mitogen-activating protein kinase) Gprl and Gpa2 (components of GPCR system) and Snf3 and Ggt2 (highand low-affinity glucose sensors) were found to be involved in signaling of glucose-induced pexophagy in Saccharomyces cerevisiae. In the methylotrophic yeast Pichia pastoris, glucose sensing protein Gss 1 was found to be important for glucose-induced pexophagy. Very few is known on mechanisms of ethanol sensing and signaling during pexophagy which is an important problem for future studies.
\end{abstract}

Key words: peroxisomes, micro- and macropexophagy, glucose sensing, signaling mechanism, Saccharomyces cerevisiae, Pichia pastoris.

$\mathrm{M}$ ethylotrophic yeasts are unique eukaryotic organisms capable of utilizing one-carbon toxic substrate, methanol. During methylotrophic growth, peroxisomes occupy $30-80 \%$ of cellular volume. Shift of methylotrophically-grown cells to media with alternative carbon sources, glucose or ethanol, induces massive peroxisome degradation. In Pichia pastoris, two morphologically distinct events have been observed, macro- and microautophagy; in other species, mostly macroautophagy was noted under massive peroxisome degradation. It was found that genes involved in non-specific autophagy (most of them are known as $A T G$ genes) also participate in carbon-induced pexophagy. Many $A T G$ genes have been discovered on the models of methylotrophic yeasts, mainly $P$. pastoris, due to convenient and easy methods for pexophagy monitoring. However, mechanisms of glucose and ethanol sensing and signaling which initiate subsequent events of micro- and macroautophagy are poorly understood. Also the nature of the low-molecular-weight effectors, derivatives of glucose and ethanol, which induce pexophagy, has not been identified.

It was found that $P$. pastoris possesses a single glucose sensor Gss1, ortholog of $S$. cerevisiae high- and low-affinity glucose sensors Snf3 and Rgt2, respectively. Gss1 protein participates in glucose sensing involved in pexophagy and glucose catabolite repression. In contrast to Saccharomyces cerevisiae, P. pastoris orthologs of GPCR signaling proteins Gprl and Gpa2 do not participate in glucose signaling of pexophagy. It is known that one of the signal proteins participating in micropexophagy in P. pastoris is $\alpha$-subunit of phosphofructokinase Pfk1, whose catalytic activity is not necessary for glucose induced micropexophagy. The role of Slt2, mitogen-activated protein kinase (MAPK), was also revealed in glucose signaling of pexophagy. Ethanol signaling was studied in mutants defective in ethanol catabolism of the yeast $P$. methanolica. It was suggested that in the medium with ethanol, glyoxylic acid is the substance which triggers pexophagy.

\section{Peroxisomes and their functions}

Peroxisomes are ubiquitous organelles present in virtually all eukaryotic cells, with exception of Archaezoa (Michels et al., 2005; Brown and Baker, 2008). Peroxisomes also known as microbodies (specific types of these organelles are also named as glyoxysomes and glycosomes) are organelles 
surrounded by a single membrane, their size is of $0.5-1.5 \mu \mathrm{m}$ at an average. They do not contain DNA, RNA and ribosomes. Cell can contain from 1-2 peroxisomes (e.g. yeast growing on glucose) to several hundred peroxisomes as mammalian cells (Till et al., 2012). According to the name, peroxisomes harbor $\mathrm{H}_{2} \mathrm{O}_{2}$-producing oxidases and decomposing latter compound catalase. However, peroxisomes are extremely versatile organelles sometimes specializing in different functions. An interesting peculiarity of peroxisomal catabolizing enzymes is their inability to produce ATP, which distinquishes them from catabolic enzymes located in mitochondria (Mast et al., 2010). Liver peroxisomes contain enzymes that enable to metabolize both very-long-chain fatty acids and $\beta$-oxidation of fatty acids and bile acid precursors with the oxidation of ingested ethanol to acetaldehyde to account for as much as $50 \%$ of the total metabolism of ethanol when substrates for the branched-chain fatty acids, phytanic acid and lipid-based xenobiotics. In yeasts, peroxisomes are responsible for initial steps of methanol and fatty acid catabolism (Veenhuis et al., 1983; van der Klei et al., 2006). In addition to catabolic, peroxisomes fulfill biosynthetic functions. In mammals, peroxisomes harbor enzymes participating in synthesis of bile acids, cholesterol and plasmalogens (Wanders et al., 2010). In mycelial fungi, peroxisomes are involved in lysine biosynthesis in yeasts and penicillin biosynthesis in mycelial fungi (Schrader and Fahimi, 2008; Aksam et al., 2009; Meijer et al., 2010). In parasitic protozoa of the genera Trypanosoma and Leishmania, glycolytic enzymes occur in a specialized peroxisome, which is known as glycosome (Michels et al., 2006). The compartmentalization of glycolytic enzymes is essential for the survival of these protozoa. Voronin bodies, which serve to plug septal pores in mycelial fungi, are also specialized peroxisomes. Plant peroxisomes are classified into three groups: glyoxisomes, leaf peroxisomes, and unspecialized peroxisomes. There are approximately 50 proteins in animal and fungal peroxisomes and approximately 100 proteins in plant peroxisomes. Proteomic and genetic studies continuously reveal new functions for peroxisomes (Michels et al. 2005; Lanyon-Hogg et al., 2010).

Defects in peroxisome structure and functions underlie many human diseases. The so called Zellweger syndrome is the best known peroxisomal inheritable disease. Patients with Zellweger syndrome fall into four groups with different defects in protein transport to peroxisomes. The defects occur in peroxisomal protein transport, which involves only peroxisome targeting signal 1 (PTS1), only PTS2, both PTS1 and PTS2, or the two (PTS1 and PTS2) protein translocation pathways and peroxisomal membrane biogenesis (Subramani, 1997). Peroxisome damage has serious consequences and is often fatal, causing death within the first year of life (Steinberg et al., 2006). It is of interest that identical genetic defects were observed in yeasts with distorted peroxisome biogenesis (so called pex mutants) (Subramani, 1998). In summary, peroxisomes are surprisingly dynamic organelles, whose dimensions, number in the cell, and protein content change in response to environmental changes. Peroxisome biogenesis is accompanied by other processes, including signal transduction (Saleem et al., 2008), chromatin modification (Wan et al., 2011), reorganization of transcription networks (Smith et al., 2002), and changes in the peroxisomal proteome (Marelli et al., 2004; Saleem et al., 2006).

Yeasts provide a convenient model to study the mechanisms of peroxisome biogenesis because cell transfer from a glucose-containing medium into a medium with oleate and/or methanol in the case of methylotrophic yeasts induces synthesis of peroxisomal enzymes and the growth and division of peroxisomes. Peroxisomes may occupy up to $80 \%$ of the cell volume in cells growing in the presence of methanol under certain conditions (Veennuis et al., 2003; Sibirny, 2012). When cells growing in the presence of methanol or oleate are transferred into a glucose-containing medium or from methanol- to ethanol-containing medium, the transfer is rapidly followed by autophagic degradation of the majority of peroxisomes (pexophagy), while one peroxisome somehow avoids this degradation in a way that is still unclear (Dunn et al., 2005). Methylotrophic yeasts appear to be one of the most convenient models for studying peroxisome biogenesis and degradation due to ability of methanol to induce massive propagation of peroxisomes. As a result, one or two small peroxisomes present in cells during growth in glucose are substituted by numerous large peroxisomes which occupy near $30 \%$ of cell volume during batch cultivation and up to $80 \%$ of cell volume under continuous cultivation under low dilution rate in methanol as sole carbon and energy source (Veenhuis et al., 2003). Inverse shift of methanol-grown cells to glucose (or ethanol) causes major reorganization of intracellular structure leading to degradation of the majority of peroxisomes due to autophagic process; consequently, from 30 to $80 \%$ of cell volume is degraded. Methods of classical and molecular genetics are well developed for several species of methylotrophic yeasts (Cregg et al., 2008; Faber et al., 1995; Lahtchev et al., 2002; Tolstorukov et al., 2007) and genome sequence of several type 
strains are publicly available (http://www.genome. $\mathrm{jp} /$ kegg-bin/show_organism?org=ppa or http:// www.pichiagenome.org/ for P. pastoris and http:// genomeportal.jgi-psf.org/Hanpo2/Hanpo2.info.

html for $H$. polymorpha). Thus, available tools permit mechanistic description of events which occur during autophagic degradation of peroxisomes in methylotrophic yeasts.

\section{General characteristics of pexophagy}

Pexophagy is the special type of autophagy, namely, autophagic vacuolar (lysosomal) degradation of peroxisomes. Autophagy could be involved in degradation of cytosolic components and some of cellular organelles (e.g. mitochondria, nucleus, endoplasmic reticulum) and macromolecular complexes (e.g. ribosomes). These specific types of autophagy have own names, such as mitophagy, piecemeal microautophagy of the nucleus (PMN), ER-phagy, ribophagy (Kiel, 2010; Sibirny, 2011).

Autophagy of cytosolic cell components mostly occurs due to non-specific process though specific autophagy is proved to be responsible for degradation of fructose-1,6-bisphosphatase and malate dehydrogenase in the baker's yeast $S$. cerevisiae. The shift of methylotrophic yeasts from methanol to glucose medium leads, in addition to autophagy degradation of peroxisome (pexophagy), to inactivation of cytosolic enzymes of methanol metabolism (formaldehyde dehydrogenase, formate dehydrogenase, fructose-1,6-bisphosphatase) and FAD synthesis (riboflavin kinase, FAD synthetase) (Brooke et al., 1986). Inactivation of fructose-1,6bisphosphatase in P. pastoris apparently occurs due to degradation process (O. Dmytruk, A. Sibirny, unpublished). However, it is not known till now where the mentioned enzyme inactivation is a result of autophagic process.

Pexophagy can occur as part of non-specific general autophagy mechanism. Apparently it takes place during yeast propagation in each medium as a component of cell constituent maintenance, housekeeping or turnover mechanism (Aksam et al., 2007). However, massive pexophagy occurs during the shift from some cultivation conditions to other ones. The last type of pexophagy is the specific one. Peroxisome degradation in $H$. polymorpha, similarly to mammal cells, could also occur in the process which is unrelated to autophagy, but involves permeabilization of the peroxisomal membrane mediated by 15-lipoxygenase (Baerends et al., 1996; Yokota, 2003). Upon lysis, the contents of the peroxisome become digested by cytosolic proteases. In $H$. polymorpha, such kind of peroxisome disintegration was observed in a constructed strain where the levels of the peroxin Pex3 had been strongly reduced. This suggests that loss of certain peroxisomal membrane proteins may destabilize the peroxisomal membrane, resulting in its lysis. Genes involved in pexophagy in methylotrophic yeasts are homologous to those found in S. cerevisiae (van Zutphen et al., 2008; Polupanov et al., 2011; Till et al., 2012; Suzuki, 2013).

The methods for isolation of the mutants defective in pexophagy have been developed in methylotrophic yeasts. All of them belong to negative selection methods when a few mutant colonies grow on plates among a huge number of wild type colonies, and mutants are identified afterwards directly in colonies using peroxisome enzyme analysis (Stasyk et al., 2008a). Apart from mutagenesis under standard mutagen treatment, the insertion mutagenesis using DNA fragments was proposed, which substantially facilitates further cloning of mutant genes (Mukaiyama et al., 2002).

Most of steps and genes involved in specific pexophagy also participate in general (nonspecific) autophagy. The steps of autophagy and participating genes are as follows (Manjithaya et al., 2010) (Fig. 1).

1. Signaling proteins required for autophagy induction: protein kinase Torl, protein kinase A, Sch9, Tap42, and phosphatase type 2A.

2. Packaging of protein or organelle transported for degradation (Atg19, Atg11, and Atg8).

3. Formation of preautophagosomal structure (Atg1, Atg11, Atg13, Atg17, Atg29, and Atg31).

4. Vesicle nucleation (Atg6, Atg9, and phosphatidylinositol 3-kinase).

5. Vesicle expansion and completion (Atg3-5, Atg6, Atg7, Atg8, Atg10, Atg12, Atg14, and Atg16).

6. Protein retrieval (Atg1, Atg2, Atg18, Atg23, and Atg27). $(\mathrm{Tlg} 2)$.

7. Homotypical fusion of isolation membrane

8. Transport and heterotypical fusion of autophagosome and vacuoles ( $\mathrm{v}$ - and t-SNAREs, Ccz1, Mon1, and HOPS complex).

9. Intravacuolar vesicle degradation (Atg15, proteinase $\mathrm{A}$, and proteinase $\mathrm{B}$ ).

From 36 Atg proteins currently known, only 17 are necessary for all types of autophagy (selective and nonselective), whereas the other 19 are specific: either used in special pathways of selective autophagy or representing species specific modifications.

Specific pexophagy pathways utilize several specific proteins which do not participate in nonspecific autophagy. During pexophagy, the specific PAS is formed, distinct from PAS structures which are produced during other types of selective autophagy. The pexophagy-specific PAS is organized 


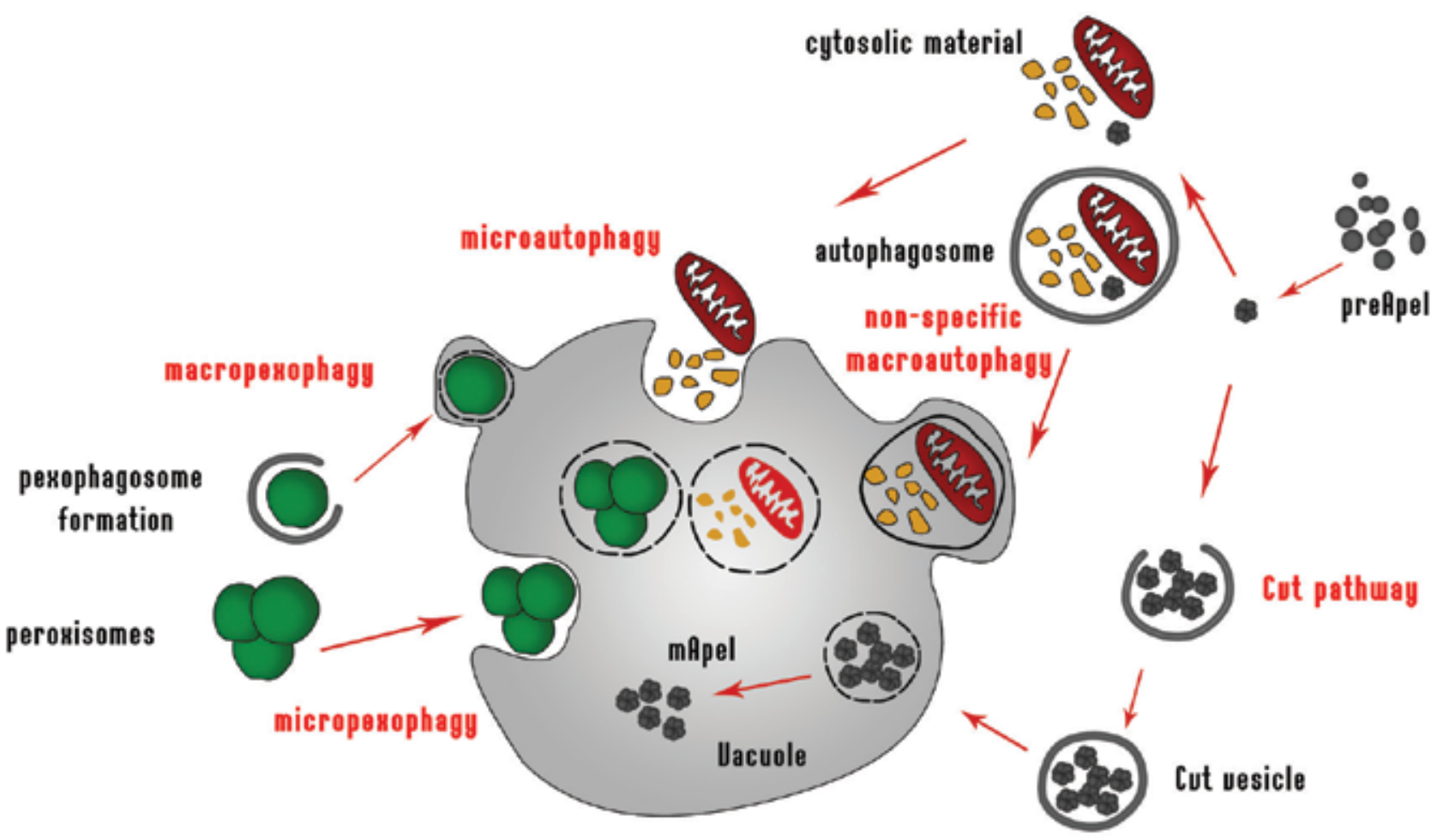

Fig. 1. Scheme of main autophagic processes

by $\operatorname{Atg} 11$, Atg17, and Atg30 (Farre et al., 2008; Nazarko et al., 2009).

Studying pexophagy in the methylotrophic yeast $P$. pastoris revealed two morphologically diverse pexophagy processes, called macropexophagy and micropexophagy (Manjithaya et al., 2010; Farre and Subramani, 2004; Tuttle and Dunn, 1995; Sakai et al., 1998; Sibirny, 2011). During macropexophagy initiated by transferring cells from methanol medium to ethanol medium, individual peroxisomes are gathered in double membrane structures called pexophagosomes that merge with vacuoles leading to degradation and repeated usage of pexophagosomal contents. During micropexophagy (occurring after transferring methylotrophically grown cells to glucose medium) peroxisome clusters are engulfed by vacuolar sequestering membranes (VSM) and specific micropexophagy apparatus (MIPA) (Mukaiyama et al., 2004), which forms a cap above a cup-shaped vacuolar sequestering membrane surrounding a peroxisome (Farre et al., 2009). Heterotypical fusion between vacuolar sequestering membranes and the specific micropexophagy apparatus transports peroxisomes inside the vacuole for degradation and repeated use of its components. The specific micropexophagy apparatus and pexophagosomes originate from the preautophagosomal structure PAS. Glucose and ethanol were shown to be specific inducers of micro- and macropexophagy, correspondingly.
There are several specific proteins involved only in pexophagy and not in the other types of autophagy: Atg24, Atg26, Atg28 and Atg30. P. pastoris Atg24 localizes to the pexophagosome-vacuole fusion complex during macropexophagy. This protein contains PtdIns3P-binding module (Ano et al., 2005a). Defect of PpAtg24 blocked pexophagy after pexophagosome formation and before its fusion to the vacuole. Apparently PpAtg24 is involved in pexophagosome fusion with the vacuole. Micropexophagy is also impaired in $\Delta a \operatorname{tg} 24$ cells. ATG26 encodes for enzyme, sterol glucoside transferase (Oku et al., 2003; Stasyk et al., 2003) which is involved in pexophagy in $P$. pastoris but not in alkane-utilizing yeast Yarrowia lipolytica. It was found that in P. pastoris, $\operatorname{Atg} 26$ is the only one necessary for pexophagy of large peroxisomes, accumulated in methanol medium. Pexophagy of small peroxisomes in this species, induced by oleate or methylamine, only partially depends on Atg26 and its product, sterol glucoside (Nazarko et al., 2007 a,b). It was also shown that P. pastoris Atg26 is required for elongation of the preautophagosomal structure (PAS) into the MIPA during micropexophagy (Yamashita et al., 2006). It was hypothesized that in P. pastoris, sterol glucosides acquired a new function during evolution related to facilitation of the elongation of the double membranes from the PAS. The enhancer function of sterol glucosides becomes essential when cells 
are challenged with elongation of the extremely large double membranes, i.e., during biogenesis of the MIPA or pexophagosome, around methanolinduced peroxisomes (Nazarko et al., 2007b).

P. pastoris $A T G 28$ also encodes pexophagy specific protein as its deficiency impairs both pexophagic mechanisms (macro- and micropexophagy) and only partially affects the general (nonspecific bulk turnover) autophagy induced by nitrogen starvation (Stasyk et al. 2006b; Nazarko et al., 2009). Atg 28 contains a coiled-coil domain that overlaps with a putative leucine zipper motif. This coiled-coil region in Atg28 may be involved in oligomerization and protein-protein interactions. It is functionally important, as modified Atg28 lacking coiled-coil is not functionally active. Atg28 is involved in the formation of one or more protein complexes specific for pexophagy and its interaction with micropexophagy-specific protein Atg35 was experimentally proved (Nazarko et al. 2011, see below). Atg28 exhibits a complex intracellular localization pattern. In most methanol-induced cells, this protein was localized to the cytosol. However, in some cells, the fusion protein was also localized to punctate structures of unknown nature associated with vacuoles and to the vacuolar membrane. In rare cases, Atg28 could be seen localized to the vacuolar matrix.

Another pexophagy-specific protein is Atg30. Two other proteins specifically involved in pexophagy and not in general autophagy or other types of specific autophagy are Pex3 and Pex14, known as peroxins also involved in peroxisome biogenesis. In $P$. pastoris, Atg30 interacts with two proteins, Pex 3 and Pex14, localized on the peroxisomal membrane (Farre et al., 2008). Effective peroxisome homeostasis probably requires their biogenesis and degradation to be coordinated. It was shown that interacting partners of Atg30 are proteins participating in peroxisome biogenesis. Thus, Pex3 is important for peroxisome biogenesis, and Pex14 - for protein import to peroxisomal matrix (Ma and Subramani 2009). In $H$. polymorpha Pex14, more exactly the $64 \mathrm{~N}$-terminal amino acid residues, are necessary for pexophagy (Bellu et al., 2001a; van Zutphen et al., 2008). Also, it was shown that during macropexophagy in $H$. polymorpha Pex 3 is removed from peroxisomes and does not undergo degradation (Bellu et al., 2002). The way Pex3 is removed from peroxisomes is unknown. Pex3 is known to be required for stabilization of a complex of proteins with a RING finger domain (Really Interesting New Gene, structural domain similar to protein zinc finger) of peroxisome importer (Hazra et al., 2002). Therefore, at this stage, besides inhibiting peroxisome biogene- sis, also destabilization of some complexes in peroxisomal membrane occurs.

In $P$. pastoris, a gene designated PDG1 (Peroxisome DeGradation) was identified whose mutations led to disturbances in peroxisome degradation (Dunn et al., 2005; O. Stasyk and A. Sibirny, unpublished data). Moreover, such mutations disturbed localization of peroxisomal proteins that, apart from peroxisomes, were also localized in cytosol, indicating disturbance in peroxisome biogenesis in pdg1 mutants. Corresponding protein Pdg1 is a membrane peroxin, which confirms its role in peroxisome biogenesis.

In $H$. polymorpha, the transcriptional repressor Tupl was shown to be essential for macropexophagy (Leao-Helder et al., 2004). Defects in orthologs of presumable corepressors involved in glucose catabolite repression, MIG1 and MIG2, also showed impairment in pexophagy (Stasyk et al., 2007). As mutants defective in MIG1 and $M I G 2$ were not affected in glucose catabolite repression, one may assume that functions of these genes are different between baker's and methylotrophic yeasts.

\section{Micro- and macropexophagy in Pichia pastoris and Hansenula polymorpha}

As was pointed above, macropexophagy could be observed in $P$. pastoris after shift of methanolgrown cells to the medium with ethanol whereas micropexophagy is observed when methanolgrown cells are transferred into medium with glucose (Tuttle and Dunn, 1995). Other methylotrophic yeast, $H$. polymorpha, is characterized by macropexophagy independently on carbon source which induces pexophagy (van Zutphen et al., 2008). During macropexophagy, multiple membrane layers sequester a single peroxisome resulting in the formation of a pexophagosome of which the outer membrane layer fuses with the vacuole where the peroxisome becomes hydrolyzed. Micropexophagy involves the uptake of a cluster of peroxisomes through direct engulfment by the vacuolar membrane (Fig. 1). Three main steps could be outlined for macropexophagy: recognition of the organelle destined for degradation, formation of the pexophagosome, and fusion with the vacuole (Fig. 1). For micropexophagy, the following steps could be distinguished: vacuolar engulfment of peroxisomes, formation of the MIPA at the peroxisomal surface, and vacuolar membrane fusion (Sakai et al., 2006).

Micropexophagy turned out to be more sensitive to a decrease of intracellular ATP compared to macropexophagy; in other words, intracellular ATP pool plays a more important role in defining 
the pexophagy pathway than the nature of the carbon substrate (Ano et al., 2005b). However, it is not known whether ATP concentration is the reason of the observed type of pexophagy or is the consequence of some other trigger mechanisms. In other methylotrophic yeasts, e.g. H. polymorpha, shift of methanol-grown cells either to glucose or ethanol leads to morphological changes described as macropexophagy. Nitrogen limitation leads in $H$. polymorpha to peroxisome degradation in by a mechanism similar to micropexophagy. However, this process occurs due to non-specific autophagic mechanism, as cytosolic components are taken up by vacuoles concomitantly with peroxisomes and therefore was named by authors as microautophagy of peroxisomes (Bellu et al., 2001b; van Zutphen et al., 2008).

During last years, genes specifically involved in macro- and micropexophagy have been identified. Gene $H$. polymorpha $A T G 25$ is specifically involved in macropexophagy. It is a coiled-coil protein and acts as the selectivity factor during macropexophagy (Monastyrska et al. 2005). This protein is located in pexophagosomes and moved there via the PAS. Atg25 is involved in the completion of sequestration of peroxisomes or in the fusion of pexophagosomes with the vacuolar membrane (Sakai et al. 2006). For the latter process, the SNARE Vam7 and the GTPase Ypt7 are also essential in $H$. polymorpha (Stevens et al., 2005).

The presence of a specific morphological structure in the micropexophagy process, the micropexophagy apparatus MIPA in P. pastoris, suggests the existence of specific genes and proteins participating in this process. Gene PFK1 encodes phosphofructokinase $1 \alpha$-subunit, which is required for peroxisome engulfment by vacuoles after transferring $P$. pastoris cells from methanol medium to glucose medium (Yuan et al., 1997). Participation of phosphofructokinase $1 \alpha$-subunit in micropexophagy does not depend on its ability to phosphorylate fructose-6-phosphate since a catalytically inactive form of this enzyme provides for normal pexophagy. Moreover, the $V A C 8$ gene (VACuole related) was identified whose product is a 60-64 $\mathrm{kDa}$ protein with so called armadillo repeat that specifically participates in micro- but not macropexophagy (Fry et al., 2006; Nazarko et al., 2007a). In mutant cells, vacuolar sequestering membrane during micropexophagy is not formed. Hybrid protein Vac8-GFP is localized on vacuolar membrane independent of Atg1, Atg9, or Atg11. Deletion of repeating armadillo did not alter Vac8 localization, but the protein lost its functionality. Vac8 probably participates in early (formation of sequestering membrane) and late (membrane fu- sion after formation of micropexophagy apparatus) micropexophagy stages. Micropexophagy and vacuole inheritance were shown to be dependent on different Vac8 domains (Oku et al., 2006). Mutations in genes $P p G C N 1, P p G C N 2, P p G C N 3$ or PpGCN4 involved in general amino acid control regulation, specifically inhibits micropexophagy after incorporation of the peroxisomes into the vacuole (Mukaiyama et al., 2002; Sakai et al., 2006), but detailed functions of these Gcn proteins are not clear. It is known that $G C N 1$ regulates translation elongation; $G C N 2$ encodes protein kinase and regulates translation initiation (eIF2 kinase); GCN3 encodes for translation initiation factor (eIF2B), whereas $G C N 4$ encodes for basic leucine zipper (bZIP) transcriptional activator of amino acid biosynthetic genes in response to amino acid starvation. The exact functions of the mentioned genes in micropexophagy remain unknown.

The new micropexophagy specific protein Atg35, the first autophagy protein with nuclear localization, was identified during the analysis of partners interacting with protein Atg28 from P. pastoris (Stasyk et al., 2006). To search for such Atg proteins, a yeast two hybrid (YTH) screening system was used for the first time. YTH screening of the genome database of $P$. pastoris DNA was carried out in $S$. cerevisiae cells using PpAtg28 as "bait" (Nazarko et al., 2011).Two sequences were revealed encoding proteins Atg35 and Rdil (Rho GDP Dissociation Inhibitor). Atg 35 consists of 463 a.a. and incorporates two putative domains: RING finger and PHD (Plant Homeo Domain). Testing $P$. pastoris mutant atg35 $\Delta$ showed that macropexophagy is normal whereas micropexophagy is impaired. Comparison of vacuolar isolating membrane formation and the micropexophagy apparatus in wild-type cells and the mutant using fluorescent microscopy revealed that formation of vacuolar isolating membranes in the mutant was normal. The micropexophagy apparatus MIPA was found in $\operatorname{atg} 35 \Delta$ cells 1.5 times less frequently than in wild-type cells, while in atg $28 \Delta$ mutant the micropexophagy apparatus was not being formed at all. However, both mutants ( $\operatorname{atg} 28 \Delta$ and $\operatorname{atg} 35 \Delta$ ) exhibited normal formation of pexophagosomes during macropexophagy, which were not formed at all in atg $1 \Delta$ mutant. Studying the role of Atg 35 in general autophagy and Cvt pathways revealed that this protein is not required for either process. Thus, Atg35 is necessary only for micropexophagy at the stage of micropexophagy apparatus formation (Nazarko et al., 2011). It is interesting that overexpression of $A T G 35$ as well as deletion of this gene both inhibit micropexophagy but do not influence macropexophagy. With ATG35 overexpression the forma- 
tion of vacuolar sequestering membranes was not disturbed, while formation of the micropexophagy apparatus was blocked. However, overexpression of ATG35 did not influence general (nonspecific) autophagy (Nazarko et al., 2011). Studying expression of genes $A T G 28$ and $A T G 35$ during peroxisome proliferation and degradation revealed that corresponding proteins are almost completely absent in ethanol medium though they are present in significant amounts in glucose and methanol medium.

Atg35 contains putative nuclear localization signal. Testing of localization of overexpressed hybrid protein Atg35-eYFP revealed that in methanol medium it was localized in the nucleus and single dot-like structures on nuclear membrane (perinuclear structure, PNS). Transfer of cells to glucose medium caused homogenous distribution of Atg35-eYFP in the nucleus. However, combined overexpression of eCFP-Atg17 caused relocalization of Atg35-eYFP to single dot-like structures of nuclear membrane during micropexophagy. Moreover, in glucose medium Atg35-eYFP on dot-like structures of nuclear membrane colocalized with one of the eCFP-Atg17 dots. Obviously eCFPAtg17 accumulation on nuclear membrane during micropexophagy is necessary for organization of single dot-like structures of nuclear membrane and involvement of Atg35-eYFP into this structure. Supposedly, Atg35 localization on single dot-like structures of nuclear membrane in glucose medium depends on Atg17 and is significant for the micropexophagy process.

Atg28 is known to interact with Atg17 (Nazarko et al., 2007a) and Atg35 (Nazarko et al., 2011). It was showed that interaction between Atg17 and Atg35 occurs due to Atg28 protein (Fig. 2. Figure 6, from Nazarko et al., 2011). Thus, Atg35 is the first revealed nuclear Atg protein participating in autophagy in yeasts. Deletion and overexpression of this gene lead to specific disturbance of micropexophagy alone. Atg35 protein functions through interaction with Atg17 and Atg28, the latter protein playing a central role in this interaction (Nazarko et al., 2011).

\section{Glucose sensing and signaling mechanisms and pexophagy \\ in $H$. polymorpha and $P$. pastoris}

When cells are transferred from methanol to glucose medium, micropexophagy ( $P$. pastoris) or macropexophagy $(H$. polymorpha) occur. Cells in some way recognize (sense) glucose and triggers glucose signal to activate all specific to micropexophagy, other pexophagy-specific and many general autophagy Atg proteins ended by peroxisome degradation. Mechanisms of glucose sensing and signaling during (micro)pexophagy is poorly understood, especially in methylotrophic yeasts.

Below we consider available data on glucose sensing and signaling connected to pexophagy.

Sensing. Mechanisms of glucose sensing have been studied in detail in $S$. cerevisiae as glucose induces complex regulatory responses, which include induction of glucose transporters, catabolite repression of hundreds of genes, catabolite inactivation of several enzymes including proteasomal and autophagic degradation of some of them. Besides, glucose is sensed for subsequent trehalose mobilization and other responses to stress factors. Still many aspects of glucose sensing in $S$. cerevisiae remain to be elucidated. Reader is referred to corresponding reviews (Ozcan and Johnson, 1999; Santangelo, 2006; Gancedo, 2008; Rubio-Texeira et al., 2010). Briefly speaking, there are two types of glucose sensors in S. cerevisiae. One is involved in glucose-dependent stress response and the other one is responsible for glucose induction and glucose catabolite repression phenomena.

Plasma membrane contains many proteins capable of glucose binding and part of them act as glucose sensors. There are 20 glucose transporters (Wieczorke et al., 1999), however, all they apparently are not involved in glucose sensing (Gancedo 2008). Specific glucose sensors can be divided in three groups. The first class of sensors comprises the classical receptor proteins or $\mathrm{G}$ protein-coupled receptors (GPCRs), which, in yeast, detect the presence of glucose and sucrose. It is responsible for glucose and sucrose control of the protein kinase A (PKA) pathway (Thevelein and de Winde, 1999) which plays a central role in the nutritional control of metabolism, stress resistance, cell cycle, growth, and transcription. All these properties are tightly controlled by the availability of nutrients in the medium, especially by the presence of a rapidly fermentable sugar, glucose. Addition of rapidly fermentable sugars to derepressed yeast cells triggers an immediate increase in the cAMP level, which in turn causes rapid activation of PKA, resulting in drastic changes in its multiple targets. The sugar-sensing GPCR system consists of the receptor Gprl and the $\mathrm{G} \alpha$ protein $\mathrm{Gpa} 2$ (Colombo et al., 1998). The second class of glucose sensors in $S$. cerevisiae is represented by two nontransporting transceptors Snf3 and Rgt2 which are sugar transporter homologs. High-affinity sensor Snf3 and low-affinity glucose sensor Rgt2 generate intracellular signal required for induction of hexose transporter genes in response to glucose (Gancedo, 2008). They, however, are not involved in glucose sensing for catabolite repression. The third class of glucose sensor is represented by intracellular 


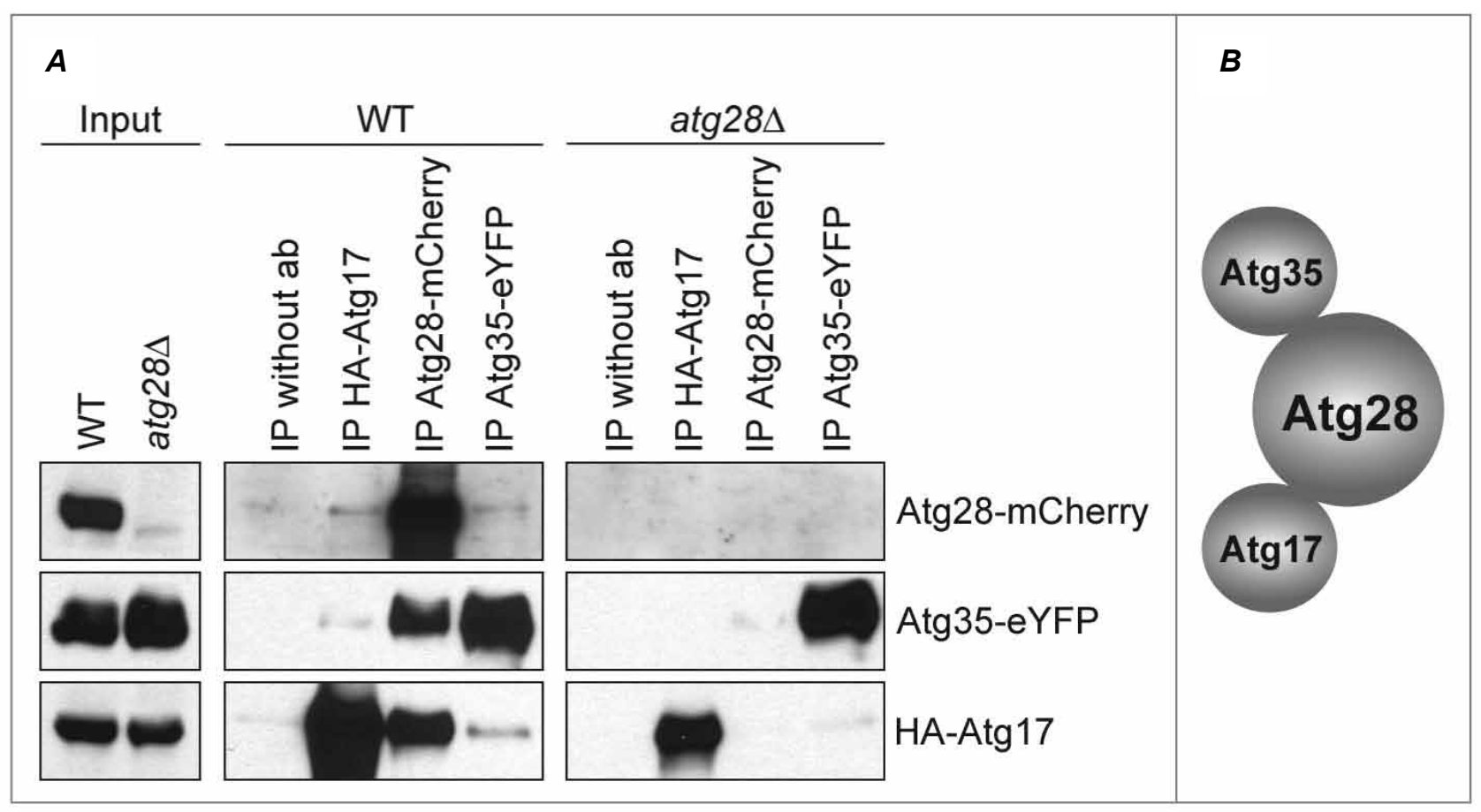

Fig. 2. Interaction between Atg35, Atg28 and Atg17. (A) co-immunoprecipitation of Atg17, Atg28 and Atg35. (B) schematic view of Atg17, Atg28 and Atg35 interactions. From: Nazarko et al., 2011

protein, the enzyme hexokinase II Hxk2. Glucose sensing of Hxk2 depends in some way on its ability to phosphorylate glucose (Rose et al., 1991). Hxk2 sensor is involved in glucose catabolite repression; it was shown a small proportion of Hxk2 is located within the nucleus (Herrero et al., 1998) and that under conditions where Hxk2 does not enter the nucleus glucose repression does not take place. These results indicate a non-metabolic role for Hxk2 that requires a nuclear localization.

Role of GPCR sensor proteins Gprl and Gpa2 and non-transporting transceptors Snf3 and Rgt2 in glucose-induced pexophagy in $S$. cerevisiae has been studied. For this, the fate of peroxisomal protein thiolase involved in fatty acid $\beta$-oxidation was analyzed. This enzyme is induced in the medium with peroxisome proliferator oleic acid. Pexophagy is started after shift of the induced cells in the medium with glucose. It was shown that knock out of each GPR1 or GPA2 leads to strong defects in glucose-activated autophagic degradation of peroxisomal thiolase (Nazarko et al., 2008a). Knock out of $S N F 3$ or RGT2 individually led to only insignificant defects in pexophagy whereas double knock out of both $S N F 3$ and $R G T 2$ resulted in practically total defect in thiolase autophagic degradation (Nazarko et al., 2008b). It was concluded that both glucose signaling components are involved in glucose sensing for pexophagy (Fig. 3;
Fig. 2, from Nazarko et al., 2008). Defects in Hxk2, however, have no effects on pexophagy in S. cerevisiae (V. Nazarko, A. Sibirny, unpublished).

In methylotrophic yeasts, we know much less on glucose sensing and signaling. In $H$. polymorpha, two glucose sensors, Gcrl and Hxs1, have been identified, along with glucose (hexose) transporter Hxt1 (Stasyk et al. 2004, 2008b). P. pastoris, on the other hand, apparently possesses only one glucose sensor, designated as Gss1 (Polupanov et al., 2011). Point or deletion mutations in GCR 1 gene of $H$. polymorpha affected glucose catabolite repression and led to constitutive presence of peroxisomes in glucose medium (Stasyk et al., 2004). However, GCR1 gene apparently is not directly involved in pexophagy. It was observed a decrease in specific activity and protein levels of peroxisomal enzyme alcohol oxidase in $g c r l$ mutant cells upon glucose adaptation, but residual alcohol oxidase levels were higher in the gcrl mutants relative to the wild type. However, these data do not demonstrate a direct involvement of Gcrl protein in pexophagy since in $g c r 1$ strains, de novo peroxisome synthesis occurred due to the defect in glucose repression. A time course examination of cell morphology revealed clear signs that pexophagy proceeds in $g c r l$ mutants. Some peroxisomes were observed sequestered by additional membrane layers typical of initial stages of macroautophagic per- 
oxisome degradation in $H$. polymorpha (Veenhuis et al., 2000). Also, in $g c r 1$ cells with fluorescently labeled peroxisomes, the pexophagic process was evident upon glucose adaptation. Shortly after the shift, GFP fluorescence was observed in vacuoles, while in methanol-growing cells it is confined to peroxisomes. These data led to the conclusion that Gcrl is not directly involved in pexophagy. Both point missense and deletion gcrl mutants continued to exhibit normal wild-type peroxisome degradation in response to ethanol.

Contrary to that, knock out mutation in another hexose sensor gene HXS1 did not lead to defect in glucose catabolite repression and led to defect in glucose transport capacity (Stasyk et al., 2008b). To study, whether HXS1 is involved in pexophagy, it was observed that in methanolpreincubated hxs $1 \Delta$ cells, alcohol oxidase activity and protein level decreased upon glucose adaptation with a rate similar to that of the wild-type strain. The $H$. polymorpha tup1 mutant deficient in pexophagy has been utilized as a positive control (Leao-Helder et al. 2004; Stasyk et al. 2007). When methanol-preinduced hxs $1 \Delta$ cells were shifted to fructose or ethanol, they also did not differ in the rates of alcohol oxidase degradation from the wild-type strain. Therefore, Hxs1, similarly to Gcrl, is not essential for glucose signaling in pexophagy in $H$. polymorpha. Thus, both of identified glucose sensors in this organism are involved in several regulatory processes exerted by glucose but not in glucose recognition for pexophagy. So, the specific glucose sensor involved in glucose-induced macropexophagy in $H$. polymorpha still needs to be found.

Situation in P. pastoris looks differently. In this organism, orthologs of GPCR sensor proteins Gpr1 and Gpa2 and glucose transceptor sensor proteins Snf3/Rgt2 have been identified. One potential ortholog of the GPRI gene and one of the GPA2 gene, that exhibit $60 \%$ and $65 \%$ similarity to their $S$. cerevisiae counterparts, respectively. Complete $G P R 1$ and GPA2 open reading frames were knocked out by gene replacement method using $S c A R G 4$ as a marker gene. Corrected knockouts of corresponding genes were confirmed by PCR. Isolated P. pastoris $\triangle g p r 1$ and $\triangle g p a 2$ mutants as well as strain SMD1163 defective in vacuolar proteases (Tuttle and Dunn, 1995) were used for studying pexophagy. Two kinds of experiments were done. In the first experiment, degradation of peroxisomal thiolase followed after the transfer of oleate-grown cells to glucose (2\%) medium, i.e., conditions were exactly the same as those which were used for $S$. cerevisiae. In the second experiment, cells were induced for peroxisome proliferation by incuba- tion on methanol $(0.5 \%)$ medium and then replica plated on the medium with ethanol or glucose. In this case, activity of a key peroxisomal enzyme of methanol metabolism, alcohol oxidase was analyzed in situ. It was found that knockout of the putative orthologs of GPR1 and GPA2 in P. pastoris has no apparent effect on both degradation of peroxisomal thiolase and inactivation of peroxisomal alcohol oxidase (Fig. 4; Fig. 3 from Nazarko et al., 2008). These mutations also had no effect on general autophagy (Nazarko et al., 2008b). Thus, in contrast to $S$. cerevisiae, PpGprl and PpGpa2 are not involved in glucose signaling for pexophagy in $P$. pastoris. It is known that in contrast to $S$. cerevisiae, Candida albicans GPR1 and GPA2 are not involved in a transient cAMP burst after glucose addition (Maidan et al., 2005). Similarly PpGprl and $\mathrm{PpGpa} 2$ could be not involved in regulation of cAMP production and it looks like glucose for pexophagy is sensed in P. pastoris by other components of the PKA-cAMP signaling pathway or only by distinct sensors which are not involved in this pathway.

Two hexose transporters were recently identified in the yeast P. pastoris, Hxt1 and Hxt2, which are transcriptionally regulated by glucose. Deletion of $P p H X T 1$ but not PpHXT2, led to the expression of alcohol oxidase in glucose medium due to glucose catabolite repression impairment. However, mutant lacking PpHxtl was normal in both respects, glucose utilization and peroxisome degradation (Zhang et al., 2010). The search for orthologs of $S$. cerevisiae glucose transceptor sensors $S N F 3$ and $R G T 2$ revealed that $P$. pastoris contains only one ortholog, designated as GSS1 (from GlucoSe Sensor) with $57 \%$ of identity and $71 \%$ of similarity to $\mathrm{ScSnf} 3$, and $46 \%$ of identity and $63 \%$ of similarity to ScRgt2 (Polupanov et al., 2012). PpGss1 also reveals high level of homology to Hxs1 protein of $H$. polymorpha $(62 \%$ of identity and $77 \%$ of similarity). PpGss1 revealed lower homology level to HpGcrl protein with $42 \%$ of identity and $60 \%$ of similarity. Like the $S$. cerevisiae sensors, PpGss1 possesses 12 transmembrane domains, a long C-terminal extension, which is the major distinguishing characteristic for glucose sensors (Özcan et al., 1998), but lacks of N-terminal peptide (52 amino acids) present in $S$. cerevisiae homologs (Fig. 5; Fig. 2 from Polupanov et al., 2012).

The strain with knock out of the gene GSS1 has been constructed. The correct integration of deletion cassette into the genome of the $\Delta g_{S S} 1$ knock-out strain was verified by Southern blot and PCR. In contrast to the wild-type cells, the strain without the GSS1 gene had impaired growth for 


\section{Glucose signaling for pexophagy in yeasts}

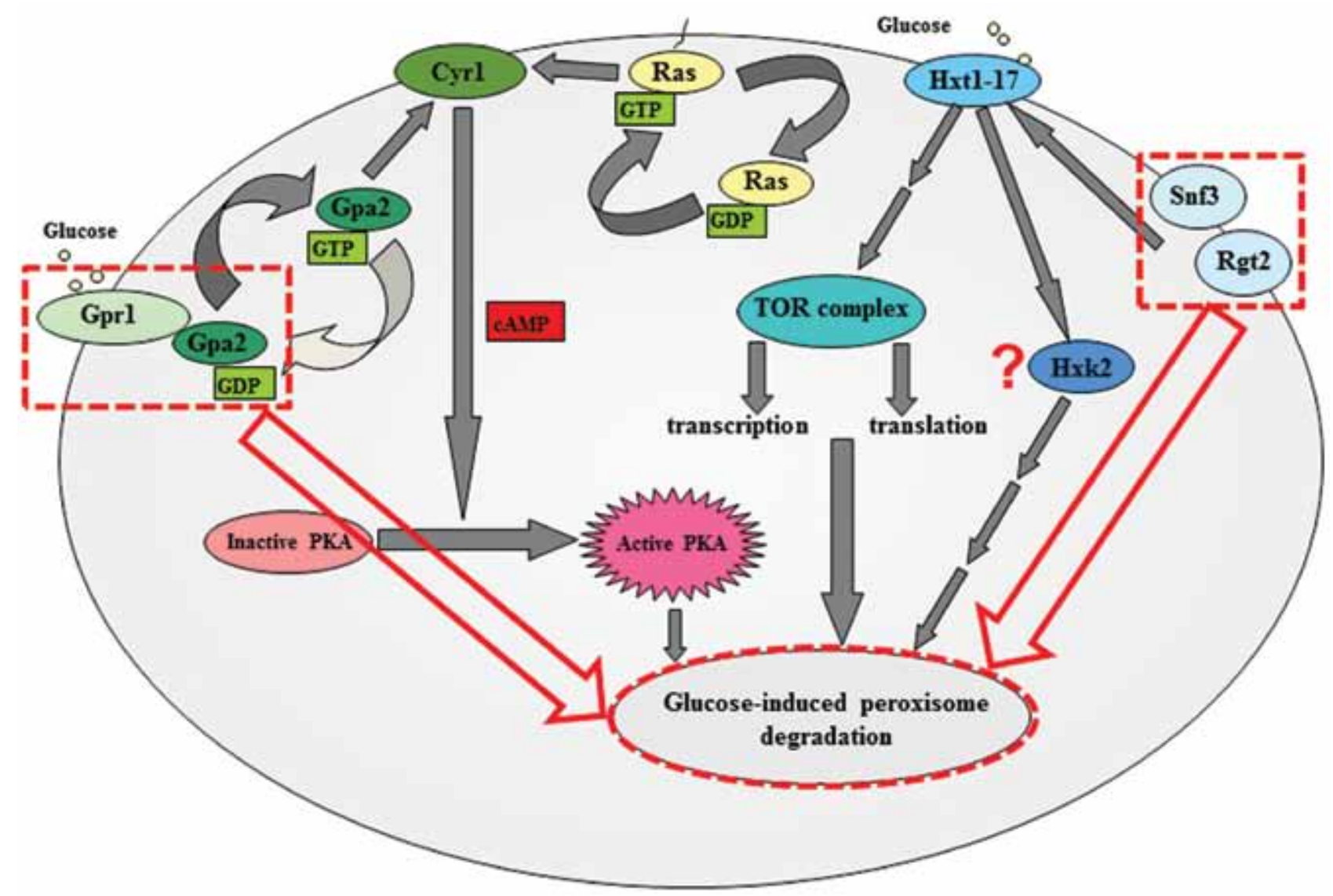

Fig. 3. Scheme of glucose signaling for pexophagy in yeasts. From Nazarko et al., 2008

\begin{tabular}{|c|c|c|c|c|c|c|c|}
\hline \multicolumn{2}{|c|}{ pep4 prb1 } & \multicolumn{2}{|c|}{$\Delta g p r l$} & \multicolumn{2}{|c|}{$\Delta g p a 2$} & \multicolumn{2}{|c|}{ WT } \\
\hline 0 & 15 & 0 & 15 & 0 & 15 & 0 & 15 \\
\hline
\end{tabular}

Fig. 4. Deletion of P. pastoris orthologs of S. cerevisiae GPR1 and GPA2 does not affect autophagy of oleateinduced peroxisomes in P. pastoris. From: Nazarko et al., 2008

both glucose concentrations $0.1 \%$ and $2 \%$. Incubation of the strains in the liquid glucose media revealed strong growth defect of $\Delta g_{s s} 1$ mutant on $2 \%$ glucose and light growth weakening on $0.1 \%$ glucose. These results suggest a primary role of $P$. pastoris Gss1 as a low-affinity glucose sensor. Despite the high homology of HpHxs1 to PpGss1, the Hxs1 deficiency had a moderate effect on glu- cose growth and utilization in $H$. polymorpha (Stasyk et al., 2008b). Deletion of GSS1 gene affects glucose catabolite repression in the methylotrophic yeast $P$. pastoris as was found in $H$. polymorpha mutants gcrl resistant to 2-deoxy-D-glucose (Stasyk et al., 2004).

Alcohol oxidase (AOX) replica plate overlay assay was used as preliminary examination of mi- 


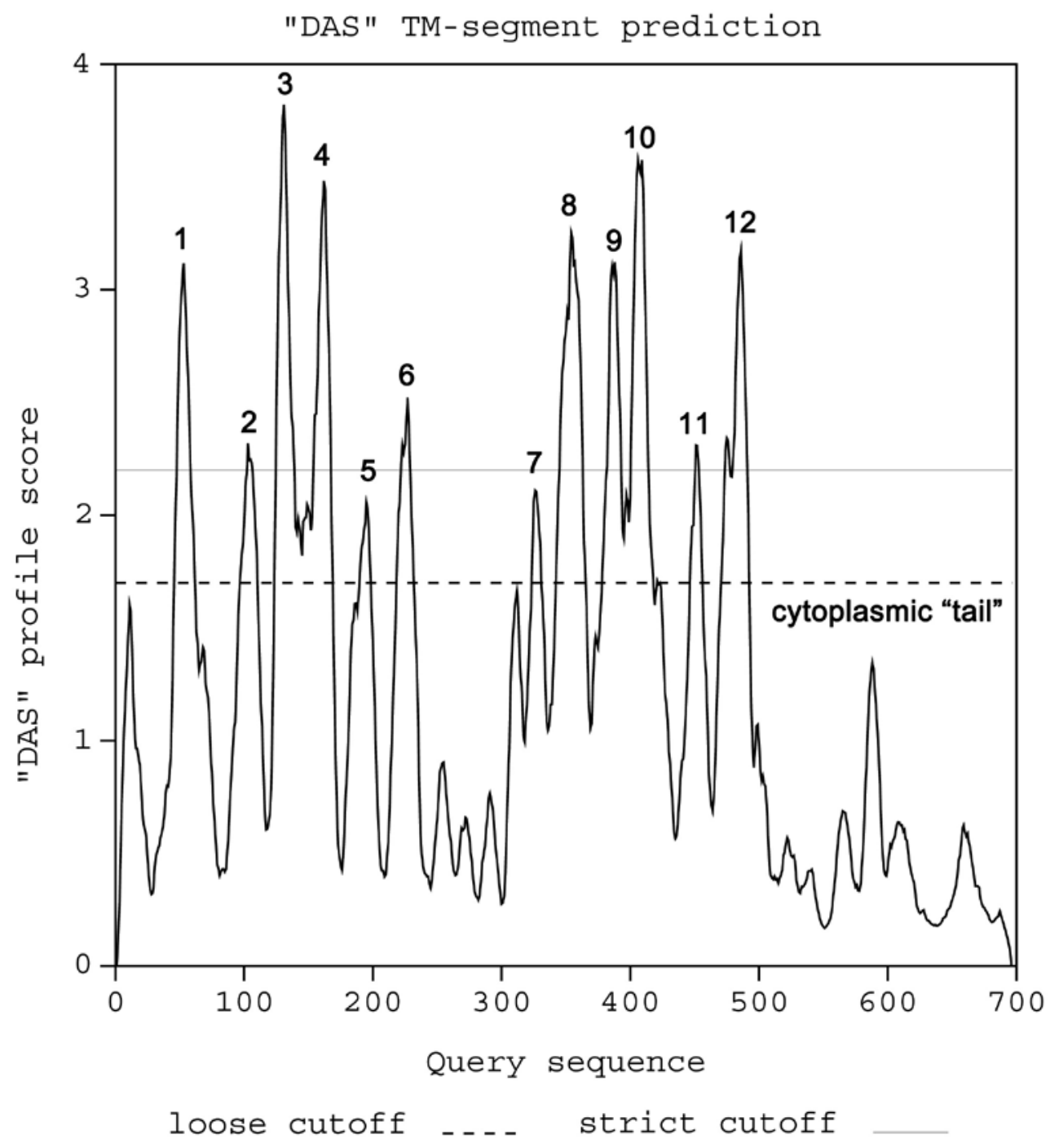

Fig. 5. Hydrophobic profile of PpGss1 protein. 12 transmembrane domains were found in PpGss1 similarly to the ScSnf3 and ScRgt2. PpGss1 has about 200 amino acid residues on the cytoplasmic C-terminus. Long cytoplasmic "tail" is the major characteristic of glucose sensors. From: Polupanov et al., 2012

cropexophagy in $\Delta g S S 1$ mutant. $P$. pastoris wildtype, $\Delta g s s 1$ and pep 4 prb1 strains with defect of vacuolar proteinases were grown on methanol minimal medium for 2 days and then they were replica plated to glucose minimal medium to induce micropexophagy. Residual alcohol oxidase activity led to the red-colored cells on the plates with glucose indicating impairment of peroxisome degradation (Sibirny and Titorenko, 1986; Stasyk et al., 2008a). The cells of $\Delta g s s 1$ mutant strain, similarly to that of pep 4 prb1 mutant, showed residual alcohol oxidase activity suggesting the block of pexophagy, unlike the wild-type strain with normal inactivation of the enzyme (Fig. 6 from Polupanov et al., 2012). These results support the hypothesis that Gss1 is important for micropexophagy in the methylotrophic yeast $P$. pastoris (Polupanov et al., 2012). In other experiment, protein samples for Western blot analysis were prepared from the cells of $P$. pastoris wild-type, $\Delta g s s 1$ and pep 4 prbl strains cultivated in methanol medium and transferred to glucose medium. For monitoring pexophagy kinetics, antibodies against $P$. pastoris alcohol oxidase were used. In the wild-type strain, level of alcohol oxidase decreased during the adaptation of the cells to glucose. Unlike the wild-type, $\Delta$ gss 1 mutant maintained the stable alcohol oxidase level up to $9 \mathrm{~h}$ of glucose adaptation. Contrary to that the wild-type cells showed no detectable alcohol oxidase band. Similarly, defect I pexophagy was observed in $\Delta$ gss 1 mutant after peroxisome induction with oleate instead of methanol. To validate 
A

AOX

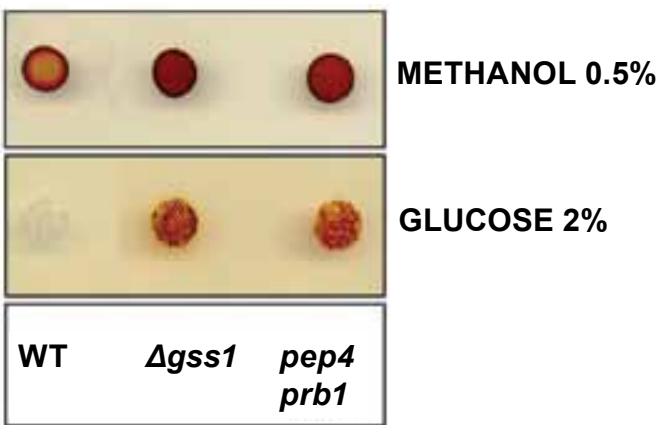

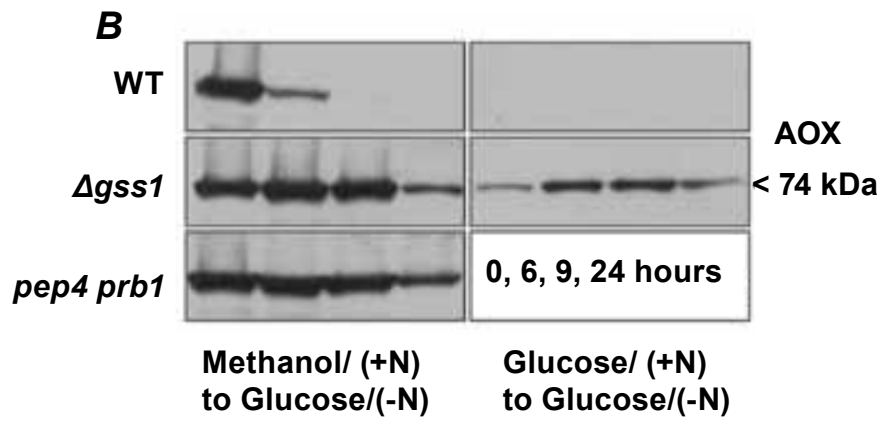

C

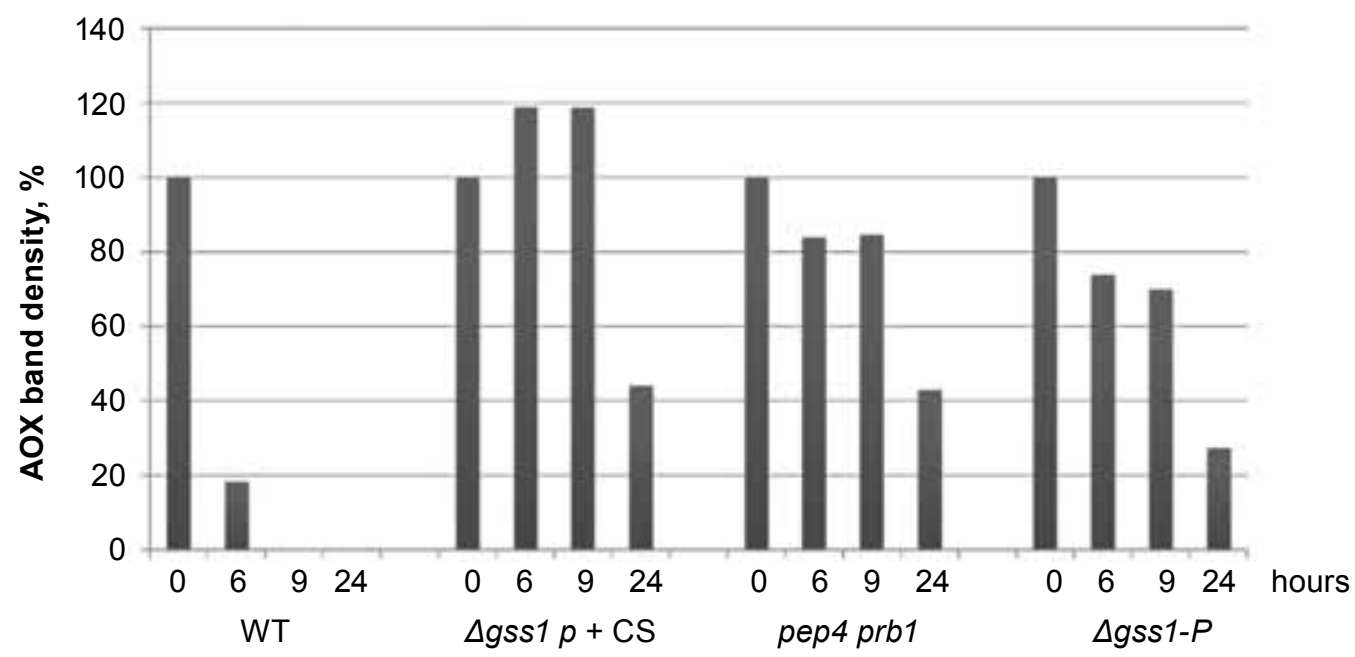

Methanol/ (+N) to Glucose/(-N)

D
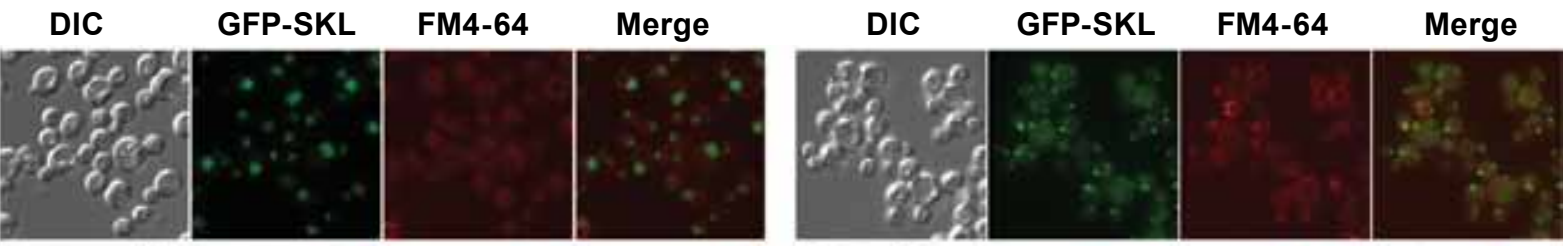

$\Delta g s s 1$
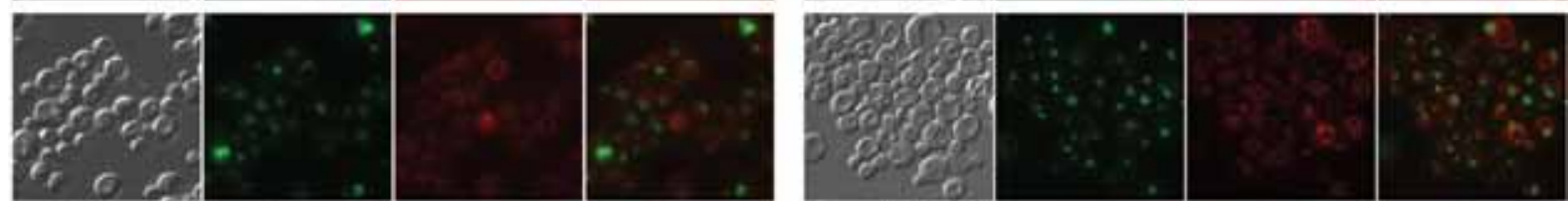

$\Delta$ atg1

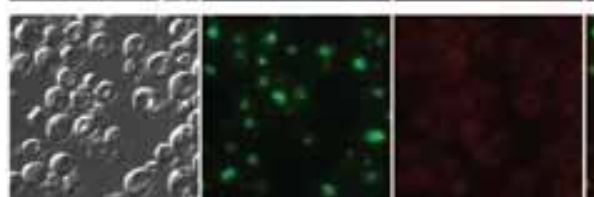

$\mathbf{O h}$
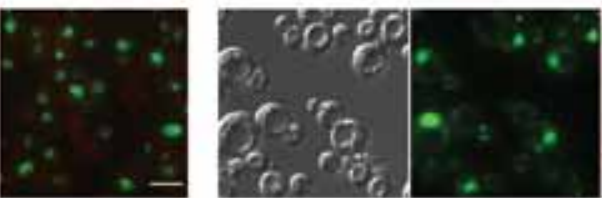

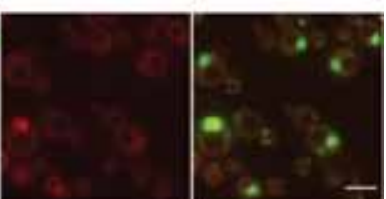

$6 \mathrm{~h}$

Methanol/ (+N) to Glucose/(-N)

Fig. 6. The deletion of P. pastoris GSS1 gene impairs micropexophagy and glucose catabolite repression. (A) Alcohol oxidase plate overlay assay. $P$. pastoris WT, $4 g s s 1$ and pep 4 prb1 strains were transferred from methanol medium to glucose medium to induce micropexophagy. Residual activity of alcohol oxidase reveals pexophagy deficiency. (B) P. pastoris WT, $4 g s s 1$ and pep4 prb1 cells were induced in methanol medium and transferred to glucose medium to induce micropexophagy. (C) Alcohol oxidase bands density (in \%) in WT, Agss1 and pep4 prb1 samples during micropexophagy. From: Polupanov et al., 2012. (D) Fluorescence microscopy studying of micropexophagy. P. pastoris $W T$ (STN017), Agss1 (SAP01) and $\triangle a t g 1$ (SAP02) cells with GFP-labeled peroxisomes were induced in methanol/ $(+N)$ medium and transferred to glucose/ $(-N)$ medium. After $6 \mathrm{~h}$ of glucose adaptation pexophagy was monitored by fluorescence microscopy. Peroxisomes were labeled with GFP-SKL and vacuolar membranes - with FM4-64 
these results, cells of $P$. pastoris were analyzed by fluorescent microscopy after the shift of methanol-grown cells into glucose medium. For this, $\Delta g s s 1$ and $\Delta a t g 1$ mutant and wild-type cells with GFP-SKL labeled peroxisomes were used. At the $6^{\text {th }}$ hour of glucose adaptation the wild-type cells showed peroxisome degradation, in contrast to the $\Delta g s s 1$ and $\Delta a t g 1$ mutants possessed peroxisome clusters surrounded by the arm-like structures of vacuolar membrane typical of micropexophagy. Data showed thus that in the cells of $\Delta g s s 1$ mutant peroxisomes degrade via micropexophagy but much slower than in the wild-type cells. Thus, the gene GSS1 seemed to be important for micropexophagy (Polupanov et al., 2012). During incubation of methanol-grown cells in ethanol medium, cells of $\Delta$ gss 1 mutant showed drop in the amount of alcohol oxidase protein, however, the process was slower than in the wild-type cells. Thus, gene GSS1 is only partially involved in macropexophagy. Fluorescent observations supported this conclusion. It was also shown that GSS1 is not involved in Cvt pathway and general (non-specific) autophagy (Polupanov et al., 2012).

It was found that that deletion of 150 residues of Gss1 leads to the alteration of phenotype, still maintaining signaling function of Gss1. At the same time, the substitution of one conserved amino acid R180K of Gss1 protein has no visible phenotype, in contrast to corresponding changes in glucose sensors from other yeast species. It has been suggested that C-terminal cytoplasmic extension of PpGss1 plays different role compared to that of its homologs in Saccharomyces cerevisiae and Hansenula polymorpha (A. Polupanov and A. Sibirny, in press). Thus, the mechanism and amino acid residues responsible for glucose sensing by Gss1 protein remain to be elucidated in the future studies.

Thus, the specific homolog of glucose transporters, transceptor sensor Gssl has been identified involved in glucose sensing for micropexophagy. It is also involved in glucose catabolite repression.

Low molecular-weight effector which triggers glucose signal for pexophagy. It is not known at the moment, which metabolite is the immediate signaling molecular initiating pexophagy signaling in glucose medium. It could be glucose or its metabolite. The observation that enzymatically inactive phosphofructokinase restored micropexophagy in glucose medium without restoration of the growth on glucose, suggests that such metabolite has to be upstream of fructose-1,6-bisphosphate (Yuan et al., 1997; Dunn et al., 2005). The study of other mutants defective in particular steps of glycolysis could help in indentification of the immediate effector of pexophagy in glucose medium.

Glucose signaling for pexophagy. Mechanisms of glucose signaling in $S$. cerevisiae have been studied in detail (Santangelo, 2006; Gancedo 2008; Rubio-Texeira et al., 2010). The scheme of glucose signaling during pexophagy in this species was provided before (Nazarko et al., 2008b). Our knowledge is quite restrictive regarding glucose signaling during pexophagy in methylotrophic yeasts. The study of thiolase and bifunctional enzyme Fox3 degradation as a peroxisomal markers showed that the Slt2 (Mpk1) mitogen-activated protein kinase (MAPK) is necessary for pexophagy but not for pexophagosome formation or other nonselective and selective forms of autophagy. It was also showed that several upstream components of its signal transduction pathway ( $\mathrm{Pkcl}, \mathrm{Bkcl}, \mathrm{Mkk1}$ and Mkk2) are also involved in glucose signaling (Manjithaya et al., 2010). MAPK Slt2 does not participate in Cvt pathway and general (non-specific) autophagy.

It was proposed that pexophagy requires the simultaneous activation of this MAPK pathway and a hexose-sensing mechanism acting through protein kinase A and cyclic adenosine monophosphate. Data, showing that orthologs of S. cerevisiae Mig1 and Mig2 are not apparently involved in glucose catabolite repression (Stasyk et al., 2007), suggest on possible strong differences in mechanisms of glucose signaling between baker's and methylotrophic yeasts.

The only work on studying glucose signaling in pexophagy in methylotrophic yeasts was published in the above mentioned article on the role of the $\alpha$-subunite of phosphofructokinase in micropexophagy (and not in macropexophagy) in P. pastoris (Yuan et al., 1997). Other components of the signaling cascade remain to be elucidated in the future research.

\section{Ethanol sensing for pexophagy \\ in methylotrophic yeasts}

Ethanol signaling for pexophagy apparently exists only in methylotrophic yeasts as in other yeast species used for pexophagy studies $(S$. cerevisiae, Y. lipolytica). Ethanol does not induce pexophagy of oleate-induced peroxisomes. However, practically nothing is known on ethanol sensing in yeasts, including in $S$. cerevisiae. Nevertheless, there have to be several quite specific mechanisms of ethanol sensing and signaling. It is known that ethanol specifically and strongly induces several proteins in S. cerevisiae, glucokinase being induced near 25 fold (Herrero et al., 1999). In S. cerevisiae, ethanol represses PDC1 coding for pyruvate decar- 
boxylase through ERA regulatory sequence (Liesen et al., 1996) and in Kluyveromyces lactis ethanol specifically represses the expression of $A D H 3$ coding for mitochondrial alcohol dehydrogenase (Saliola et al., 2007). In methylotrophic yeasts, ethanol specifically activates the repression of synthesis of the enzymes involved in methanol metabolism in addition to pexophagy (Sibirny et al., 1989). We do not know if there are specific ethanol sensors in cytoplasmic membrane, till now no such protein was reported. Possibly ethanol is sensed by some intracellular specific sensors and/or ethanol metabolizing enzymes. There are ecrl and adh1 mutants of the methylotrophic yeast Pichia methanolica (Pichia pinus MH4) known in which ethanol is unable to repress synthesis of the peroxisomal enzymes involved in methanol catabolism (Sibirny et al., 1987; Sibirny et al., 1991). In adh1 mutants, ethanol and methanol are utilized simultaneously and hybrid peroxisomes are produced which apparently maintain enzymes for both methanol and ethanol metabolism, whereas in ecrl mutants methanol is first utilized from the mixture of both alcohols. Though the genes were not isolated, adh1 mutation apparently tagged one of alcohol dehydrogenases whereas ECR 1 gene possibly encodes protein involved in ethanol sensing.

In $P$. methanolica, attempts were made to identify a derivative of ethanol initiating pexophagy in ethanol medium. Mutants defective in distinct steps of ethanol utilization have been isolated (Tolstorukov et al., 1989; Sibirny et al., 1990). It was found that pexophagy was affected in mutants icl1 defective in isocitrate lyase suggesting that isocitrate is immediate ethanol metabolite initiating pexophagy.

Thus, the mechanisms of sensing and signaling in glucose- and ethanol-induced pexophagy in yeast, in general, and methylotrophic yeasts, in particular, are far from understanding. At this moment, we do not know exact glucose sensors and components of signal transmitting to pexophagy machinery. In the case of ethanol-induced pexophagy, our knowledge is at the initial stage. It could be envisaged that studies in this field will be more active in the nearest future and we will have soon the mechanistical picture of pexophagy sensing and signaling by glucose and ethanol in methylotrophic yeasts.

\section{Acknowledgements}

The work in the field of pexophagy in the autor's laboratory was supported by grant N F46.1/012 from the State Foundation for Basic Research «Key State Laboratory of Molecular and Cellular Biology», Ukraine.

\section{ЗЧИТУВАННЯ І ПЕРЕДАЧА СИГНАЛУ АВТОФАГОВОЇ ДЕГРАДАЦІЇ ПЕРОКСИСОМ (ПЕКСОФАГІЯ) У ДРІЖДЖІВ}

\section{A. А. Сибірний}

${ }^{1}$ Інститут біології клітини НАН України, Львів; ${ }^{2}$ University of Rzeszow, Poland

Дріжджові клітини, подібно клітинам інших евкаріотів, мають внутрішньоклітинні органели, у тому числі пероксисоми, відомі також як мікротіла. Ензими оксидативного метаболізму: головним чином, оксидази (що утворюють пероксид водню), каталаза, деякі ензими гліоксильного циклу і ензими, залучені в катаболізм незвичайних джерел вуглецю (n-алканів, метанолу) розташовані в пероксисомах. Пероксисоми відіграють особливо важливу роль у метилотрофних дріжджах, в унікальних мікроорганізмах, здатних утилізувати одновуглецеву сполуку метанол. На метанолі відбувається активна проліферація і біогенез пероксисом; внаслідок цього ці органели можуть займати від 30 до $80 \%$ клітинного об'єму. Після того як клітини, що виросли на метанолі, переміщуються в середовища, які містять багатовуглецеві субстрати, такі як глюкоза або етанол, надлишок пероксисом деградує за допомогою автофагової деградації пероксисом або пексофагії. Існують 36 генів, пов'язаних із AuTophaGy і відомих як гени $A T G$; їхні продукти також беруть участь у пексофагії. Водночас, мало відомо про механізми зчитування і передачі сигналу глюкози та етанолу, які ініціюють процес пексофагії. Було виявлено протеїни Pfk1 $(\alpha$-субодиниця фосфофруктокінази), Slt2 (мітогенактивуюча протеїнкіназа), Gprl i Gpa2 (сенсори глюкози з високою і низькою спорідненістю), які брали участь у передачі сигналу в разі пексофагії у Saccharomyces cerevisiae, спричиненою глюкозою. Чутливий до глюкози протеїн Gss1 мав істотний вплив на пексофагію, зумовлену глюкозою, у метилотрофних дріжджів Pichia pastoris. Про механізми зчитування і передачі сигналу етанолу під час пексофагії відомо дуже мало, що $€$ важливим напрямом подальших досліджень.

К л ючов і слова: пероксисоми, мікроi макропексофаги, глюкозозчитувальні i сигнальні механізми, Saccharomyces cerevisiae, Pichia pastoris. 


\section{СЧИТЫВАНИЕ И ПЕРЕДАЧА СИГНАЛА АУТОФАГОВОЙ ДЕГРАДАЦИИ ПЕРОКСИСОМ (ПЕКСОФАГИЯ) У ДРОЖЖЕЙ}

\section{A. А. Сибирныйт,2}

${ }^{1}$ Институт биологии клетки НАН Украины, Львов; ${ }^{2}$ University of Rzeszow, Poland

Дрожжевые клетки, подобно клеткам других эукариотов, имеют внутриклеточные органеллы, в том числе пероксисомы, известные также как микротела. Энзимы оксидативного метаболизма: в основном, оксидазы (образующие пероксид водорода), каталаза, некоторые энзимы глиоксильного цикла и энзимы, вовлеченные в катаболизм необычных источников углерода (n-алканов, метанола) расположены в пероксисомах. Пероксисомы играют особенно важную роль в метилотрофных дрожжах, в уникальных микроорганизмах, способных утилизировать одноуглеродное соединение - метанол. На метаноле происходит активная пролиферация и биогенез пероксисом; в результате органеллы могут занимать от 30 до $80 \%$ клеточного объема. После того как клетки, выросшие на метаноле, перемещаются в среды, содержащие многоуглеродные субстраты, такие как глюкоза или этанол, избыток пероксисом деградирует посредством аутофаговой деградации пероксисом или пексофагии. Существуют 36 генов, связанных с AuTophaGy и известных как гены $A T G$; их продукты также принимают участие в пексофагии. В то же время мало известно о механизмах считывания и передачи сигнала глюкозы и этанола, которые инициируют процесс пексофагии. Были обнаружены протеины Pfk1 ( $\alpha$-субъединица фосфофруктокиназы), Slt2 (митогенактивирующая протеинкиназа), Gpr1 и Gpa2 (сенсоры глюкозы с высоким и низким сродством), которые участвовали в передаче сигнала пексофагии у Saccharomyces cerevisiae, вызванной глюкозой. Чувствительный к глюкозе протеин Gss1 оказывал существенное влияние на пексофагию, вызванную глюкозой, у метилотрофных дрожжей Pichia pastoris. О механизмах считывания и передачи сигнала этанола во время пексофагии известно очень мало, что является важным направлением дальнейших исследований.

К л ю чвы е с лова: пероксисомы, микро- и макропексофаги, глюкозосчитывающие и сигнальные механизмы, Saccharomyces cerevisiae, Pichia pastoris.
1. Aksam E. B., Koek A., Kiel J. A. et al. // Autophagy. - 2007. - 3. - P. 96-105.

2. Aksam E. B., de Vries B., van der Klei I. J. et al. // FEMS Yeast Res. - 2009. - 9. - P. 808820.

3. Ano Y., Hattori T., Oku M. et al. // Mol. Biol. Cell. - 2005a. - 16. - P. 446-457.

4. Ano Y., Hattori T., Kato N. et al. // Biosci Biotechnol Biochem. - 2005b. - 69. P. 1527-1533.

5. Baerends R. J., Rasmussen S. W., Hilbrands R. E. et al. // J. Biol. Chem. - 1996. - 271. P. 8887-8894.

6. Bellu A. R., Komori M., van der Klei I. J. et al. // J. Biol. Chem. - 2001a. - 276. - P. 4457044574.

7. Bellu A. R., Kram A. M., Kiel J. A. et al. // FEMS Yeast Res. - 2001b. - 1. - P. 23-31.

8. Bellu A. R., Salomons F. A., Kiel J. A. et al. // J. Biol. Chem. - 2002. - 277. - P. 42875-42880.

9. Brooke A. G., Dijkhuizen L., Harder W. // Arch. Microbiol. - 1986. - 145. - P. 62-70.

10. Brown L. A., Baker A. // Mol. Membr. Biol. 2008. - 25. - P. 363-375.

11. Colombo et al. 1998

12. Cregg J. M., Tolstorukov I., Kusari A. et al. // Methods Enzymol. - 2008. - 463. - P. 169-189.

13. Dunn W. A. Jr., Cregg J. M., Kiel J. A. et al. // Autophagy. - 2005. - 1. - P. 75-83.

14. Faber K. N., Harder W., Ab G. et al. // Yeast. 1995. - 11. - P. 1331-1344

15. Farre J. C., Subramani S. // Trends Cell Biol. 2004. - 14. - P. 515-523.

16. Farré J. C., Manjithaya R., Mathewson R. D., Subramani S. // Dev. Cell. - 2008. - 14. P. 365-376.

17. Farré J. C., Krick R., Subramani S. et al. // Curr. Opin. Cell Biol. - 2009. - 21. - P. 522530.

18. Fry M. R., Thomson J. M., Tomasini A. J. et al. // Autophagy. - 2006. - 2. - P. 280-288.

19. Gancedo J. M. // FEMS Microbiol. Rev. 2008. - 32. - P. 673-704.

20. Hazra P. P., Suriapranata I., Snyder W. B. et al. // Traffic. - 2002. - 3. - P. 560-574.

21. Herrero P., Martínez-Campa C., Moreno F. // FEBS Lett. - 1998. - 434. - P. 71-76.

22. Herrero P., Flores L., de la Cera T. et al. // Biochem. J. - 1999. - 343. - P. 319-325.

23. Kiel J. A. // Philos. Trans. R. Soc. Lond. B Biol. Sci. - 2010. - 365. - P. 819-830.

24. Lahtchev K. L., Semenova V. D., Tolstorukov I. I. et al. // Arch. Microbiol. - 2002. - 177. P. $150-158$. 
25. Lanyon-Hogg T., Warriner S. L., Baker A. // Biol. Cell. - 2010. - 102. - P. 245-263.

26. Leão-Helder A. N., Krikken A. M., Lunenborg M. G. et al. // FEMS Yeast Res. 2004. - 4. - P. 789-794.

27. Liesen T., Hollenberg C. P., Heinisch J. J. // Mol. Microbiol. - 1996. - 21. - P. 621-632.

28. Ma C., Subramani S. // IUBMB Life. 2009. - 61. - P. 713-722.

29. Maidan M. M., De Rop L., Serneels J. et al. // Mol. Biol. Cell. - 2005. - 16. - P. 1971-1986.

30. Marelli M., Smith J. J., Jung S. et al. // J. Cell Biol. - 2004. - 167. - P. 1099-1112.

31. Manjithaya R., Nazarko T. Y., Farré J. C. et al. // FEBS Lett. - 2010. - 584. - P. 1367-1373.

32. Mast F. D., Fagarasanu A., Knoblach B. et al. // Physiology (Bethesda). - 2010. - 25. P. 347-356.

33. Meijer WH, Gidijala L, Fekken S et al. // Appl. Environ. Microbiol. - 2010. - 76. - P. 57025709.

34. Michels P. A., Moyersoen J., Krazy H. et al. // Mol. Membr. Biol. - 2005. - 22. - P. 133-145.

35. Michels P. A. M., Bringaud F., Herman M. et al. // Biochim Biophys Acta. - 2006. - 1763. P. $1463-1477$

36. Monastyrska I., Kiel J. A., Krikken A. M. et al. // Autophagy. - 2005. - 1. - P. 92-100.

37. Mukaiyama H,. Oku M., Baba M. et al. // Genes Cells. - 2002. - 7. - P. 75-90.

38. Mukaiyama H., Baba M., Osumi M. et al. // Mol. Biol. Cell. - 2004. - 15. - P. 58-70.

39. Nazarko T. Y., Polupanov A. S., Manjithaya R. R. et al. // Mol. Biol. Cell. - 2007a. - 18. P. 106-118.

40. Nazarko T. Y., Farré J. C., Polupanov A. S. et al. // Autophagy. - 2007b. - 3. - P. 263-265.

41. Nazarko V. Y., Thevelein J. M., Sibirny A. A. // Cell Biol. Int. - 2008a. - 32. - P. 502-504.

42. Nazarko V. Y., Futej K. O., Thevelein J. M. et al. // Autophagy. - 2008b. - 4. - P. 381-384.

43. Nazarko T. Y., Farré J. C., Subramani S. // Mol. Biol. Cell. - 2009. - 20. - P. 3828-3839.

44. Nazarko V. Y., Nazarko T. Y., Farré J. C. et al. // Autophagy. - 2011. - 7. - P. 375-385.

45. Oku M., Warnecke D., Noda T. et al. // EMBO J. - 2003. - 22. - P. 3231-3241.

46. Oku M., Nishimura T., Hattori T. et al. // Autophagy. - 2006. - 2. - P. 272-279.

47. Ozcan S., Dover J., Johnston M. // EMBO J. 1998. - 17. - P. 2566-2573.

48. Ozcan S., Johnston M. // Microbiol. Mol. Biol. Rev. - 1999. - 63. - P. 554-569.

49. Polupanov A. S., Nazarko V. Y., Sibirny A. A. // Cell Biol. Int. - 2011. - 35. - P. 311-319.
50. Polupanov A. S., Nazarko V. Y., Sibirny A. A. // Int. J. Biochem. Cell Biol. - 2012. - 44. P. 1906-1918.

51. Rose M., Albig W., Entian K. D. // Eur. J. Biochem. - 1991. - 199. - P. 511-518.

52. Rubio-Texeira M., Van Zeebroeck G., Voordeckers K. et al. // FEMS Yeast Res. 2010. - 10. - P. 134-149.

53. Sakai Y., Oku M., van der Klei I. J. et al. // Biochim. Biophys. Acta. - 2006. - 1763. P. 1767-1775.

54. Sakai Y., Koller A., Rangell L. K. et al. // J. Cell Biol. - 1998. - 141. - P. 625-636.

55. Saleem R. A., Smith J. J., Aitchison J. D. // Biochim. Biophys. Acta. - 2006. - 1763. P. 1541-1551.

56. Saleem R. A., Knoblach B., Mast F. D. et al. // J. Cell Biol. - 2008. - 181. - P. 281-292.

57. Saliola M., Getuli C., Mazzoni C. // FEMS Yeast Res. - 2007. - 7. - P. 693-701.

58. Santangelo G. M. // Microbiol. Mol. Biol. Rev. - 2006. - 70. - P. 253-282.

59. Schrader M., Fahimi H. D. // Histochem. Cell Biol. - 2008. - 129. - P. 421-440.

60. Sibirny A. A. // Biochemistry (Moscow). 2011. - 76. - P. 1279-1290.

61. Sibirny A. A. // Mol. Biol. (Moscow). - 2012. 46. - P. 11-26.

62. Sibirny A. A., Titorenko V. I. // Ukr. Biokhim. Zhurn. - 1986. - 58. - P. 65-68 (in Russian).

63. Sibirny A. A., Titorenko V. I., Efremov B. D. et al. // Yeast. - 1987. - 3. - P. 233-241.

64. Sibirny A. A. Genetic control of methanol and ethanol metabolism in the yeast Pichia pinus. In: Proc. 6th Intern. Symp. on Genetics of Industrial Microorganisms. Starsbourg, France. Ed. by H. Heslot. Soc. Franc. Microbiol., 1990. - 1. - P. 545-554.

65. Sibirny A. A., Titorenko V. I., Teslyar G. E. et al. // Arch. Microbiol. - 1991. - 156. P. 455-462.

66. Smith J. J., Marelli M., Christmas R. H. et al. // J. Cell Biol. - 2002. - 158. - P. 259-271.

67. Stasyk O. V., Nazarko T. Y., Stasyk O. G. et al. // Cell Biol. Int. - 2003. - 27. - P. 947-952.

68. Stasyk O. V., Stasyk O. G., Komduur J. et al. // J. Biol. Chem. - 2004. - 279. - P. 8116-8125.

69. Stasyk O. V., Stasyk O. G., Mathewson R. D. et al. // Autophagy. - 2006. - 2. - P. 30-38.

70. Stasyk O. G., van Zutphen T., Kang H. A. et al. // FEMS Yeast Research. - 2007. - 7. P. 1103-1013.

71. Stasyk O. V., Nazarko T. Y., Sibirny A. A. // Methods Enzymol. - 2008a. - 451. - P. 229239. 
72. Stasyk O. G., Maidan M. M., Stasyk O. V. et al. // Eukaryot. Cell. - 2008b. - 7. - P. 735-746.

73. Steinberg S. J., Dodt G., Raymond G. V. // Biochim. Biophys. Acta. - 2006. - 1763. P. 1733-1748.

74. Stevens P., Monastyrska I., Leão-Helder A. N. et al. // FEMS Yeast Res. - 2005. - 5. P. 985-997.

75. Subramani S. // Nat. Genet. - 1997. - 15. P. 331-333.

76. Subramani S. // Physiol. Rev. - 1998. - 78. P. 171-188.

77. Suzuki K. // Cell Death Differ. - 2013. - 20. P. 43-48.

78. Thevelein J. M., de Winde J. H. // Mol. Microbiol. - 1999. - 33. - P. 904-918.

79. Till A., Lakhani R., Burnett S. F., Subramani S. // Int. J. Cell Biol. - 2012. - 2012. - P. 512721.

80 Tolstorukov I. I., Efremov B. D., Benevolensky S. V. et al. // Yeast. - 1989. - 5. P. 179-186.

81. Tolstorukov I., Cregg J. M. // Methods Mol. Biol. - 2007. - 389. - P. 189-202.

82. Tuttle D. L., Dunn W. A. Jr. // J. Cell Sci. 1995. - 108. - P. 25-35.
83. van der Klei I. J., Yurimoto H., Sakai Y. et al. // Biochim. Biophys. Acta. - 2006. - 1763. P. 1453-1462.

84. van Zutphen T., van der Klei I. J., Kiel J. A. // Methods Enzymol. - 2008. - 451. - P. 197-215.

85. Veenhuis M., Van Dijken J. P., Harder W. // Adv. Microb. Physiol. - 1983. - 24. - P. 1-82.

86. Veenhuis M., Salomons F. A., van der Klei I. J. // Microsc. Res. Tech. - 2000. - 51. - P. 584600.

87. Wan Y., Saleem R. A., Ratushny A. V. et al. // Mol. Cell. Biol. - 2009. - 29. - P. 2346-2358.

88. Wanders R. J., Duran M., Loupatty F. J. // J. Inherit. Metab. Dis. - 2010. - 35. - P. 5-12.

89. Wieczorke R., Krampe S., Weierstall T. // FEBS Lett. - 1999. - 464. - P. 123-128.

90. Yamashita S., Oku M., Wasada Y. et al. // J. Cell Biol. - 2006. - 173. - P. 70-717.

91. Yokota S. // Microsc. Res. Tech. - 2003. 61. - P. 151-160.

92. Yuan W., Tuttle D. L., Shi Y. J. // J. Cell Sci. 1997. - 110. - P. 1935-1945.

93. Zhang P., Zhang W., Zhou X. et al. // Appl. Environ. Microbiol. - 2010. - 76. - P. 61086118. 